\title{
The SCANDINAVIAN MODEL - PROSPECTS AND CHALLENGES
}

\author{
TORBEN M. ANDERSEN
}

CESIFO WORKING PAPER No. 1903

CATEgory 3: Social Protection

JANUARY 2007

\footnotetext{
An electronic version of the paper may be downloaded

- from the SSRN website:

- from the RePEc website:

www.SSRN.com

- from the CESifo website:

www.RePEc.org

www.CESifo-group.de
} 


\title{
THE SCANDinAVIAN MODEL - PROSPECTS AND CHALLENGES
}

\begin{abstract}
Scandinavian countries are often portrayed in policy debates as model examples having shown how to square concerns for efficiency and equity. The core principle of the Scandinavian welfare model is an individual entitlement to public sector provisions combined with collective financing via taxes. However, a high employment rate is needed to ensure financial viability of this model. The Scandinavian model faces several challenges which affect the possibilities of maintaining a high employment ratio, namely, demographic changes, a growth dilemma and globalization. This paper discusses how these challenges affect the need and scope for reforms of the Scandinavian welfare model.
\end{abstract}

JEL Code: H1, E62, F22, P1.

Keywords: fiscal sustainability, welfare state, demographics, globalization.

\author{
Torben M. Andersen \\ School of Economics and Management \\ University of Aarhus \\ 8000 Aarhus C \\ Denmark \\ tandersen@econ.au.dk
}

January 2007 


\section{1.}

\section{Introduction}

The Scandinavian countries share a number of common characteristics. They are small and open economies, they have a high living standard, and the distribution of income is relatively even. Moreover, the public sector is responsible for the distribution and allocation of a substantial amount of resources (above $50 \%$ of GDP). The latter includes both a social safety net, which entitles most without any income to an income transfer, and a provision of welfare services with relatively high standards. Scandinavian countries are therefore often portrayed as having shown how to square concerns for efficiency and equity, and are often referred to in policy debates as model examples.

The core principle of the Scandinavian welfare model is that the entitlement to public sector provisions is individual while the financing is collective, in the sense that they are tax financed. There is no relationship between the tax payment of an individual and its entitlement (common pool property). This principle of universalism is reflected in important welfare arrangements like education, health care, pensions etc. A distinguishing feature is that the standard of the public provisions is high. This means that the living standard offered, in particularly for those people with no or only marginal attachment to the labour market, is relatively high, and that the standard of public services is high in the sense that it meets the needs and requirements of most people. The latter implies that public service provision is neither a fall back option of last resort nor providing a minimum to be supplemented by privately financed additions.

It is difficult to point to specific schemes or institutions that can be characterized as unique for the Scandinavian countries ${ }^{1}$. Considering specific welfare arrangements one finds similar schemes in other countries. Hence, the Scandinavian welfare model is to some extent characterized by the way policy measures have been bundled rather than by unique elements. Note also that although the Scandinavian countries share a number of similarities, there are important differences in the micro-structure of the specific welfare arrangements (see e.g. Hansen (2004), Nordic Social-Statistical Committee (2005)).

Given that a large proportion of resources are allocated via the public sector it may be asserted that the welfare model is non-market based. It has been suggested that labour has become decommodified in the sense that a decent living standard is guaranteed without having to sell labour in the market. To some, this may seem as if the idea of social citizenship advanced by Marshall (1950) has been implemented to ensure a universal right to an income "not proportionate to the market value of the claimant” (Marshall, 1950, p100). This is not a correct representation of the Scandinavian welfare model for two important reasons, namely, that the model is very employment oriented, and entitlements are not in general unconditional. 
The Scandinavian welfare model is very market oriented ${ }^{2}$ with respect to labour. This is directly reflected in the fact that the public sector is a large actor in the labour market demanding labour for the provision of public services, and that various welfare arrangements like e.g. day care serve the double function of facilitating the supply of labour for females (see e.g. Graafland (2000)). For the welfare state to be financially viable, it is necessary that a large proportion of the population is in employment. The reason is simple. If out of job most people would be entitled to a transfer, while in job their income and thus tax payment is higher. Hence, for given ambitions with respect to welfare standards and tax payments the employment share of the population is the key balancing point for the financial viability of the model. This feature has pros and cons. On the pro side is that the focus on employment is one of the reasons why Scandinavian countries are among the countries in the world with the highest income levels, and why the income distribution is fairly equal. On the con side are the problems of combining generous welfare arrangements with incentives to work (including education, mobility etc.).

While entitlements are universal in the sense that they are right-based, this does not imply that access is unconditional. For some services this is absurd, and for transfers this would correspond to an unconditional basic income (demo-grant). Access to welfare arrangements does usually presume a need, that is, access is conditional on being in a particular situation (illness, lack of working capability etc.). Eligibility for income transfers is also conditional (means-tested) in the sense that access to social assistance constituting the basic element of the social safety net is conditional on the individual being unable to support itself ${ }^{3}$. Hence, entitlements are not unconditional, and they have a labour market focus.

The aim of matching requirements for high labour force participation (high employment ratio) with concerns for equality is not an easy task. It raises a number of problems and dilemmas in a number of policy areas. It is also interesting to note that the most severe crises in recent times in the Scandinavian countries have been associated with significant and persistent drops in employment rates. This was the case for Denmark and Norway in the 1970s and 1980s leading to substantial economic imbalances and unsustainable public finances, and a similar situation occurred in Sweden during the 1990s’ crises.

In a forward looking perspective, the Scandinavian model faces several challenges which in one way or another all have implications for the requirements to ensure a high employment ratio. The challenges include: i) changing demographics increasing the dependency ratio significantly not least due to increasing longevity, ii) increased demand for services (e.g. health care and education) as well as leisure stressing the financial balance of the system, iii) effects of globalization both directly (e.g. migration and tax base mobility) and indirectly (increased tax distortions due to changes in product/labour market structures). To this list could be added the challenge related to the risk of eroding norms as well as polarization and 
segregation weakening the financial viability of the model, but also the homogeneity and support on which the model relies (see e.g. Lindbeck et. al. (2004)). It is beyond this paper to discuss this issue.

While many of the challenges - demographics and globalization - are not different or worse than in many countries, the consequences and possible remedies must be seen in perspective of the welfare regime adopted. The key question is thus whether and how it is possible to address these problems without making fundamental changes to the welfare model.

This paper discusses the particular way in which the various challenges affect the need and scope for reforms of the Scandinavian welfare model, and it discusses some of the proposals for reforms recently made in the Scandinavian countries. The paper is organized as follows: Section 2 highlights a few facts on the Scandinavian countries in a comparative perspective. Some of the basic policy dilemmas arising in the Scandinavian welfare model are briefly outlined in section 3 as a prelude to a discussion of the challenges faced by Scandinavian countries. The discussion of these challenges (section 4: demographic changes, section 5: the growth dilemma, section 6: globalisation) focuses on the employment question. The final section 7 comments on the policy perspectives.

\section{A brief characterization of the Scandinavian countries in international comparison}

In the Scandinavian countries, a substantial amount of resources are allocated and distributed via the public sector amounting to about $50 \%$ of GDP, cf. figure 1. Roughly, these expenditures are equally split between consumption and transfers.

\section{Figure 1: Allocation of resources via the public sector, 2004}

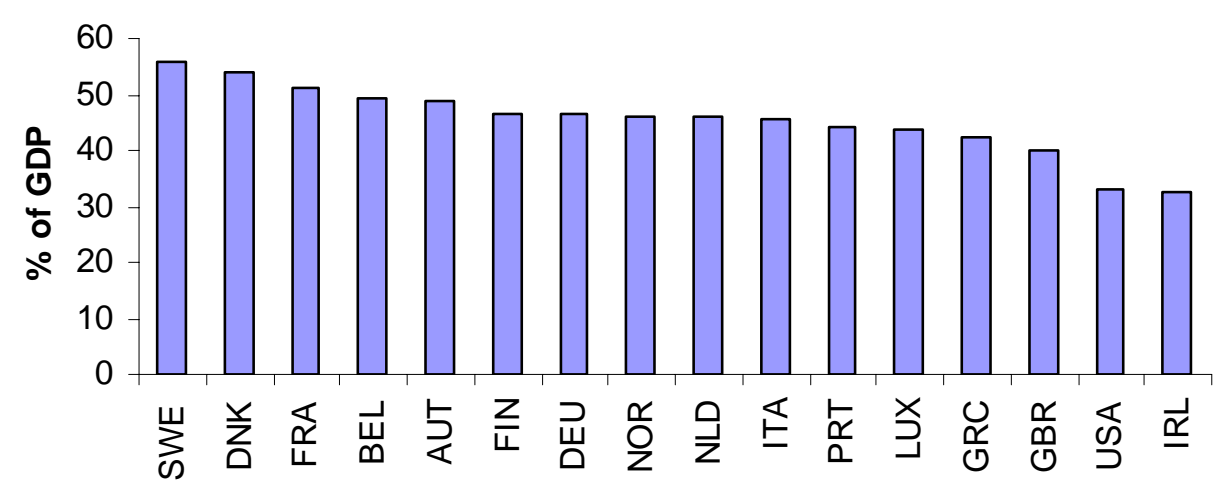

Note: Total public outlays in percentage of GDP Source: OECD 
Public expenditures are mainly tax financed, and a key issue is how taxation ${ }^{4}$ affects labour markets. The total tax wedge on labour is an indicator of the implications taxation has for the labour market, cf. figure 2. The Scandinavian countries are among the European countries with the highest tax wedges. However, it may be misleading to compare these across countries without accounting for differences in labour market structures. The interrelationship between wages and taxes involves a common pool problem. Taxes levied on labour income also finance expenditures to the benefit of workers. Accordingly, if wage formation is centralized, negotiators will perceive that taxes finance expenditures to the benefit of workers, and therefore the tax to wage spill-over will be smaller. Oppositely, with very decentralized wage setting, negotiators will not perceive that their own tax payments have a significant influence on aggregate tax revenue, and therefore the tax to wage spill-over will be stronger. Historically, labour markets have been very centralized (see e.g. Boeri et al (2000)) and this has tended to mute some of the tax distortions.

\section{Figure 2: Total tax wedge on labour}

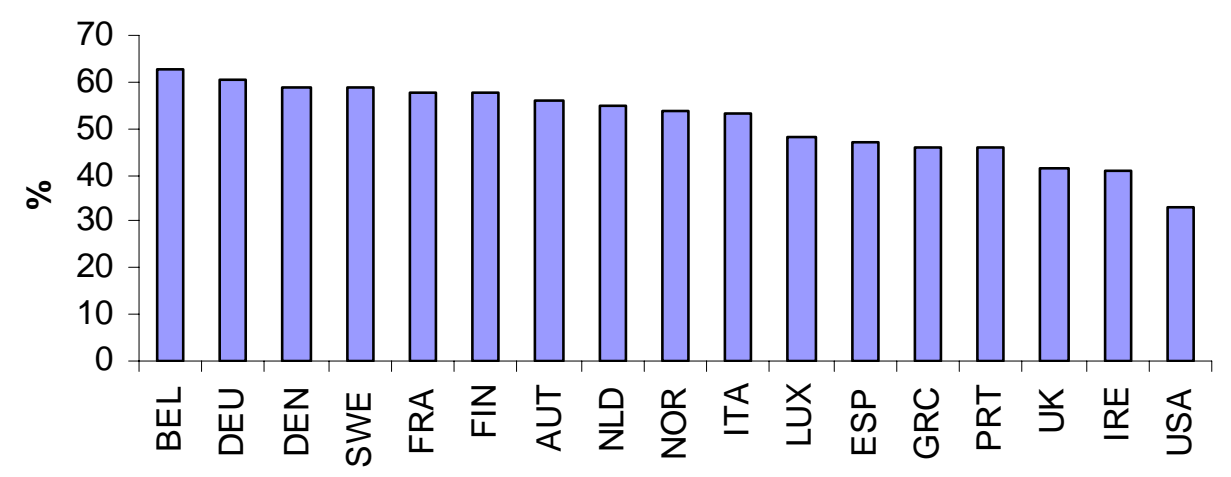

Note: For an average production worker Source: Velfærdskommissionen (2006)

Given the extended form of the welfare state in the Scandinavian countries, it follows that the ratio between employed and non-employed in the population plays a key role. For given ambitions with respect to welfare services and the social safety net as well as given tax rates there is a lower bound on the overall dependency ratio consistent with financial viability of the welfare state. Therefore, the viability of the model depends on keeping a high labour force participation rate, i.e. the Scandinavian welfare model is employment oriented. As seen from figure 3, labour force participation rates are high in international comparison, especially for females. This is the outcome of a process which took place during the 1960s and 1970s, where the labour force participation rate for women rose to almost the same level as for men. Hence, the Scandinavian welfare model is a "gender split breadwinner" model. 
Figure 3: Labour force participation, 2004, OECD Countries

\section{Males}

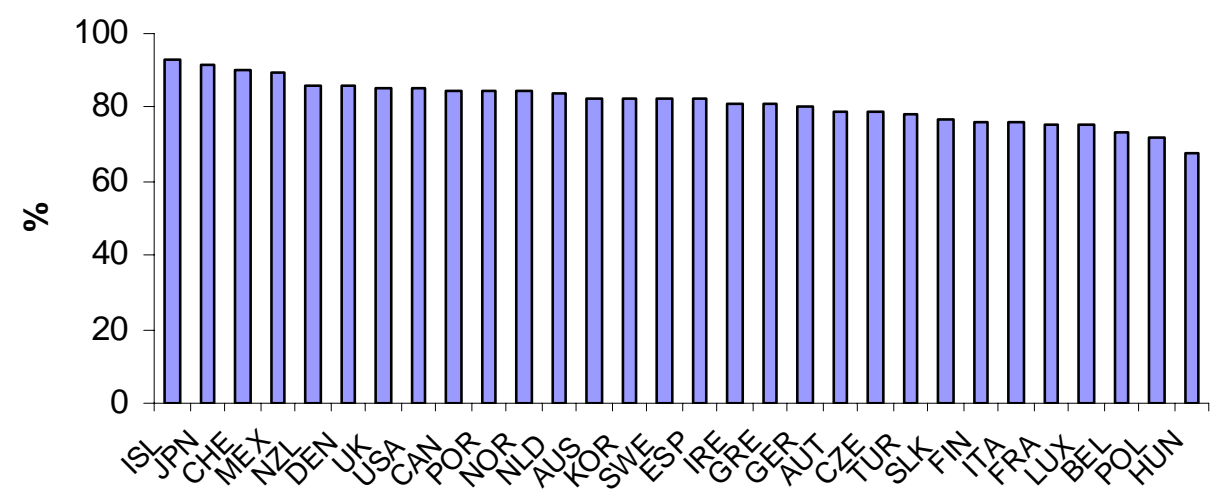

Females

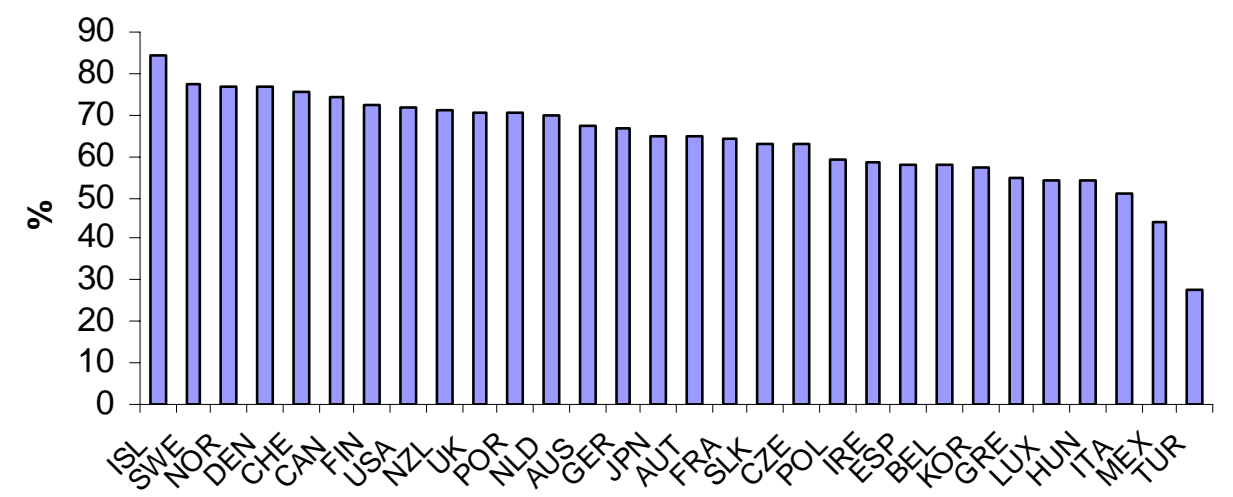

Note: Age group 15-64.

Source: OECD

One way to underline the importance of keeping a high employment rate is to consider the sensitivity of public finances to variations in employment. A drop in employment of $1 \%$ would imply a deterioration of net-public revenue of about $0.8 \%$ due to the combined effects of lower tax revenue and increasing expenditures on transfers ${ }^{5}$. Hence, if employment drops by $1 \%$, the financial burden resting on the remaining employed increases by almost $1 \%$ if the welfare arrangements are to remain financially viable. This is basically a different representation of the so-called automatic stabilizers (see e.g. van der Noord (2001)). In a business cycle perspective large automatic stabilizers contribute to the smoothening of business cycle fluctuations. However, what is a blessing in short-run business cycle context may be a curse in a structural context if the employment ratio for various reasons is dwindling. 
Figure 4: Annual working hours, OECD Countries 2004

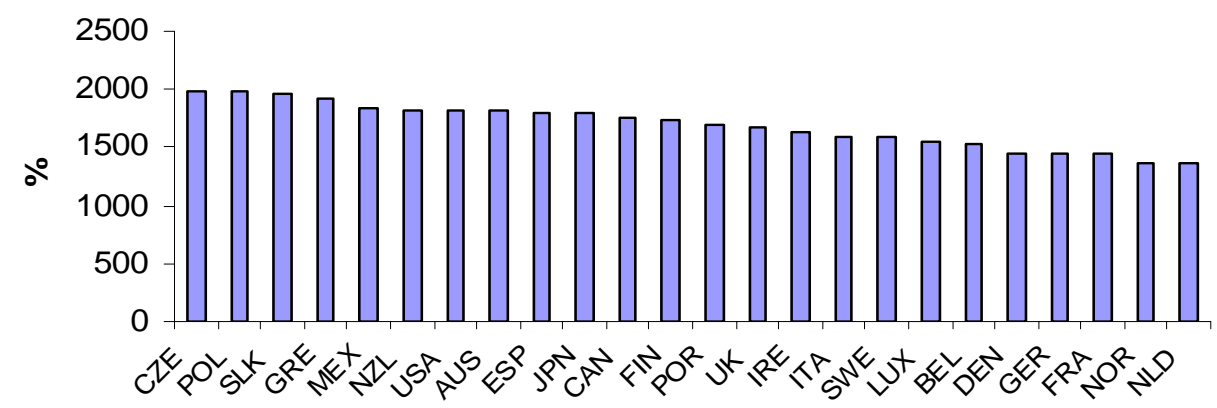

Source: OECD

Although labour force participation is high, it should be pointed out that working hours are not high by international standards, cf. figure 4. This may partly be a consequence of the high labour force participation rate for both sexes and partly be due to the distortions caused by the high tax wedge on labour income. 
Figure 5: The social contract in the Scandinavian countries - age dependent net contributions

\section{Denmark}

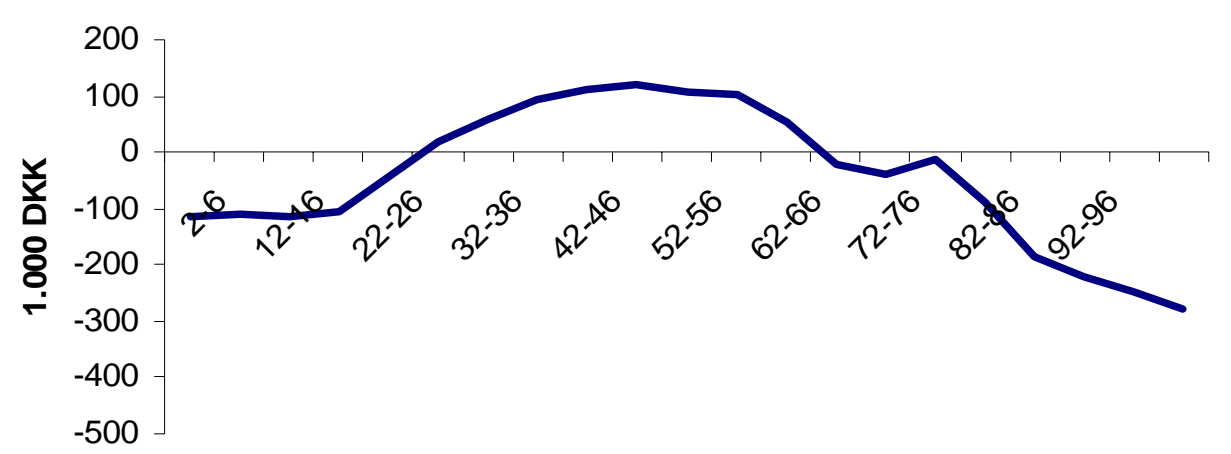

Age

\section{Norway}

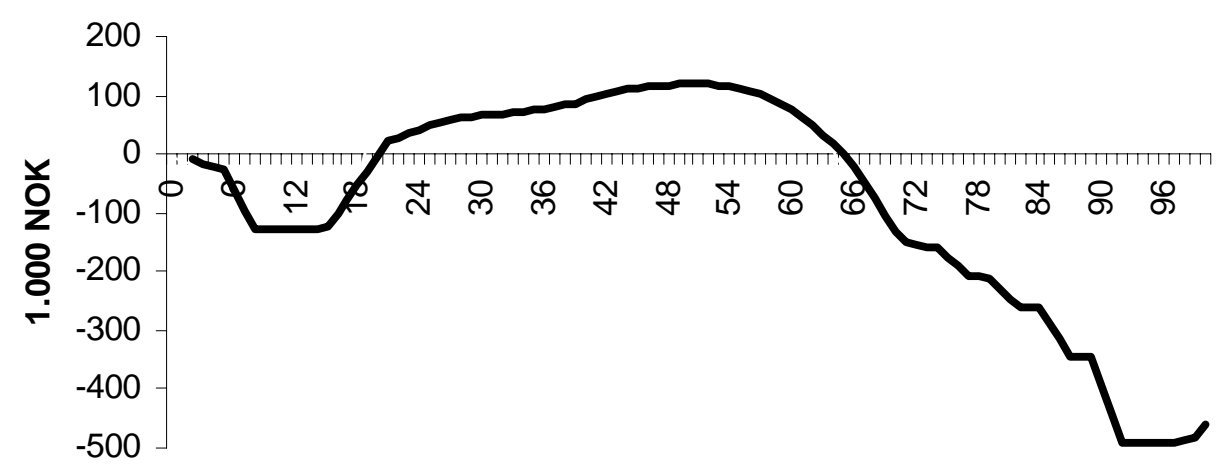

Age

\section{Sweden}

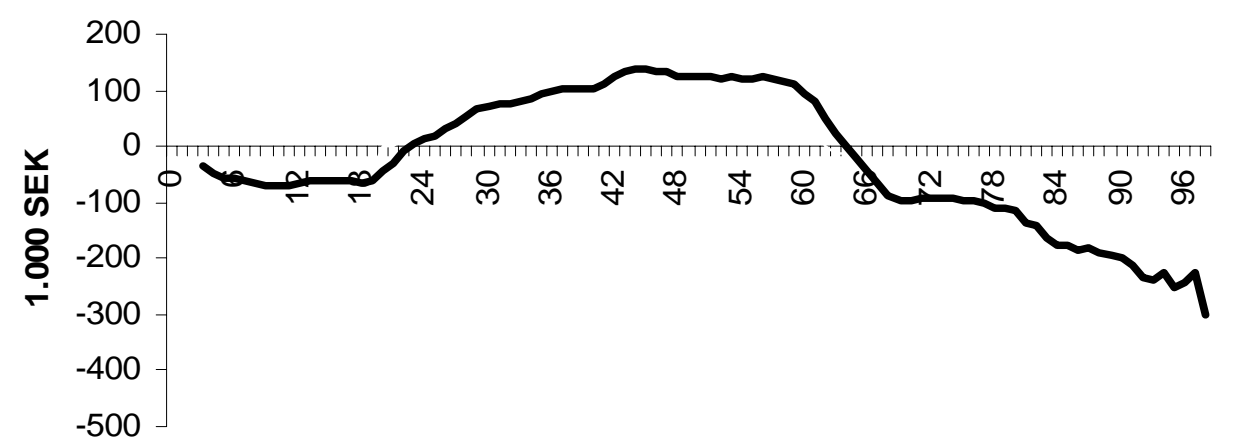

Age

Note: In national currencies, averages over age groups

Source: Data from Velfærdskommissionen (2005), Finansdepartementet Norge, and Finansdepartementet, Sverige. 
It is a natural consequence of the extended welfare arrangement that there is a strong life-cycle dependency in the net contributions to the welfare state. The average person is a net-beneficiary as child and young (child care, education etc.), a net-contributor during work life, and a net-beneficiary as old (pensions, old age care). Naturally, at a given moment, there is a substantial dispersion across individuals of a given age, in particular for age groups normally considered to be work ages. Figure 5 displays the dependency of the netcontribution on age for the three Scandinavian countries, and it clearly demonstrates the strong life-cycle pattern. This captures a social contract between generations in which individuals in work age groups via (net) tax payments provide the financial basis for welfare arrangements directed toward young and elderly members of society. In its outset, the social contract is of the pay-as-you-go type. This extended social contract - the cradle to grave model - is one key element of the Scandinavian welfare model.

The Scandinavian countries are often portrayed as having escaped the efficiency-equity trade off since these countries have both a high income level and low inequality, cf. figure 6 . The egalitarian perspective is reflected in entitlements, tax structure, wage structure etc. In international comparison, income inequality is low measured by standard metrics like the Gini-coefficient, cf. figure 6 . However, more notable is the fact that the welfare model in particular offers (relatively) high compensation levels for groups with no or only a marginal attachment to the labour market (see. e.g. Hansen (2004))

Figure 6: Efficiency vs Equity

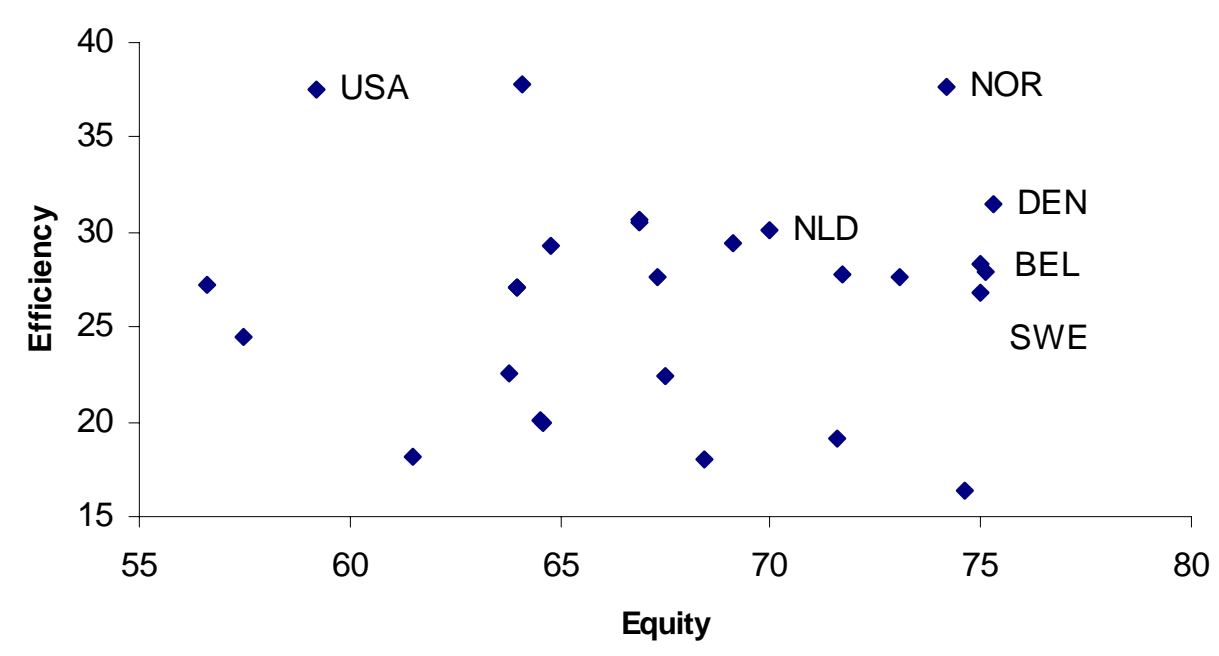

Note: Efficiency measured by GDP per capita (PPP), and equality as 100- Gini coefficient. Countries with GDP per capita above 15,000 per year are included. Only countries at the frontier are identified. Gini coefficients are latest available estimate, GDP is from 2003.

Source: UNDP, Human Development Report 


\section{Policy dilemmas in the Scandinavian welfare model}

There are a number of recurrent themes surfacing in the policy debate and which are intimately linked to the aims and characteristics of the Scandinavian welfare model.

A key issue is the balance between distributional concerns and incentives for labour market participation (the extensive margin). Concerns for redistribution and social balance imply that the level of transfers offered (and minimum wages) is high. Working poor is not a policy option in keeping a high employment ratio. This raises two fundamental questions. One is how to ensure that there is an incentive to work ${ }^{6}$ in particular for low income groups. It is difficult to use economic incentives. Making transfers and supplements (for e.g. housing and day-care) income dependent would imply very large effective marginal tax rates, and yielding tax credits raise the standard problem of how to target the intended groups without giving tax concession to a large part of the employees.

There are some non-economic measures which can be used to ensure that high labour market participation is consistent with generous transfers. One measure is concerned with requirements for availability including active job search and willingness to move and commute for jobs etc. Another is to introduce various workfare elements in social policies, that is, claiming unemployment benefits or social assistance requires participation in various activation measures. This class of instruments has the aim of affecting the reservation demands for job searchers and minimizing the scope for passively claiming transfers. In principle, such nonmarket instruments can ensure the same incentive to be active in the labour market as reductions in the level of benefits. ${ }^{7}$ As such, they seem ideal instruments in a welfare state. However, these instruments are not without problems. The schemes are administrative in nature and therefore costly to administer. Activation schemes in particular may be costly depending on the nature of activities used. Moreover, a too strong commitment on the part of the political system in taking responsibility for ensuring "full employment" may have detrimental effects for search activities and on the incentives underlying wage formation (see e.g. Calmfors et al. (2002)). In addition, there are other and possibly more important issues. Activation can have two aims. One is to reduce a moral hazard problem which arises when people are claiming support although they are voluntarily without labour income (enjoying leisure or working in the black sector). The other aim is concerned with improving people’s chances of finding a job (via job-training, improved qualifications etc.). The former can be achieved by very simple schemes (time demanding schemes), but they will often be considered humiliating. Implementation of such measures is also encountering the screening paradox, that is, if the measure succeeds in separating "deserving” and "non-deserving” claimants, it appears as if one is punishing the "deserving" claimants. Activation measures aiming at improving qualifications may overcome these constraints but are more resource demanding, and they raise the difficult question of deciding which qualifications would be in demand. 
The active labour market policy has been highlighted as one of the reasons why Sweden in the 1970s and 1980s managed to escape high open unemployment when most other OECD countries were facing a severe unemployment problem. In Denmark, a number of reforms during the 1990s made a shift from a very passive orientation of the labour market policy primarily focussing on income maintenance to an active policy including workfare elements. Spending on ALMP is high in Denmark and Sweden.

Social benefits set a floor under wage formation (via legal minimum wages or negotiated minimum wages) ${ }^{8}$. Since these policies are motivated by the fact that low market wages are not acceptable, it is an implication that some unemployment eventually follows. Not all of those who would have a market wage below the wage floor will be in demand if they are to be paid the minimum wage. Some unemployment is therefore a cost of redistributive policies. The question is how this cost can be minimized. One obvious answer is educational policies to ensure that the supply of unskilled labour is sufficiently small. Educational policies have always had a strong standing in the Scandinavian countries for the twofold reason that it is a key element in providing equal opportunities and breaking social heritage etc., and because it is indirectly part of the redistributional policy. Moreover, it enhances growth by better exploitation of the entire human capital potential in the population

One tension in educational policies is that a compressed wage structure and high taxation have a negative effect on the return to education. There is a demand and supply side to the compressed wage structure ${ }^{9}$. It implies that highly qualified labour is relatively cheap in the Scandinavian countries, something which has also recently been highlighted as a parameter of importance in international competition. However, on the supply side it reduces the return and thus the incentive to undertake education. In a recent study of the return to education, de la Fuente (2004) finds that the private return to education in Denmark and Sweden is below the average for the included $14 \mathrm{EU}$ countries. The importance of the return to education for educational decisions should be seen relative to the fact that public financing of education is substantial. The Scandinavian countries constitute the OECD top of countries spending most public funds as a share of GDP on education.

A different route by which to consider education is to try to assess the outcomes by indicators of the educational level and the quality of educations. In the quantitative dimension measured by the share of the population holding a PhD degree, Sweden is at the OECD top, while Norway and Denmark are below average. The fraction of youth not receiving any education beyond compulsory schooling is low in Norway and Sweden, but still almost 1/5 of a generation in Denmark. Recent PISA tests put the Scandinavian countries at an average position in terms of acquired skills for youth at the age of 15 (OECD 2004). Hence, 
while the Scandinavian countries may have had an educational lead in the past, it is hard to argue that this is the case today. In the medium to long run, this may have important consequences for growth and international competitiveness.

A recurrent theme is the extent to which labour markets are distorted by the high level of taxation. To some it may seem inconceivable that labour markets can work under such high taxation, and yet they do. There are several remarks to be made on this. First, taxation releases both income- and substitution effects of taxation, and hence the quantitative importance for labour supply of a high level of taxation is not a priori given. Second, for the hours decision the evidence reported in figure 4 can be taken as evidence of a distortion caused by taxation. However, working hours should also be seen in the perspective of the high labour force participation of both males and females, hence working hours at the family level are not low in the Scandinavian countries. Finally, centralized labour markets have undoubtedly (see Summers et. al. (1993)) played a role in minimizing distortions by muting the effects of taxes on wages and working hours (in centralized bargaining the effects on the public sector budget balance are internalized). An interesting and open question is whether the recent tendency towards more decentralized wage formation would imply that the distortionary effects of the high level of taxation would become more visible.

Welfare arrangements may enhance efficiency via the implied pooling and diversification of risk. Since both contributions to and benefits from the welfare state are dependent on various events, the collective welfare policies constitute an elaborate implicit insurance contract (involving inter- and intragenerational risk sharing). One basic insight from the recent economics literature on the economics of the welfare state ${ }^{10}$ is that a system with ex-post redistribution (based on actual income, labour market status, health etc.) in an ex ante perspective also serves as an insurance mechanism. If agents are risk averse, this can have direct welfare effects as well as incentive effects (via sharing and diversification of risk) that can enhance efficiency. Pursuing this line of thought reveals an important trade-off between the insurance and incentive effects of various policy instruments. The difficult policy problem is to ensure that the insurance mechanisms do not develop into permanent support, that is, the temporary nature of an insurance scheme has to be ensured.

As an example of the insurance vs. incentive effects one can consider the structure of the Danish labour market which has drawn much attention recently under the heading of the flexicurity model. The basic idea is that flexible rules for hiring and firing of workers combined with a generous unemployment insurance scheme achieve a balance between flexibility in adjustment for firms and income security for workers. As such, the model can be seen as a way to square concerns for efficiency with social security. Since Denmark has a low unemployment rate and in many respects a sound macroeconomic situation, it has been inferred that this can be attributed to the flexicurity model. However, two points need to be taken into account in this 
relation (see Andersen and Svarer (2006)). The first is that the basic ingredients of the flexicurity model were also in place during the 1970s and 1980s when unemployment was persistent at double digit numbers. The main change in labour market policy during the 1990s was a shift from a passive to an active orientation in labour market policies including a shortening of benefit duration and introduction of workfare elements in the unemployment benefit and social assistance scheme. Second, despite the low registered unemployment rate it is the case that about a third of the population in the work age group is receiving some form of income transfer. Hence, the model has not been unconditionally successful in ensuring high labour force participation.

\section{The demographic challenge}

Demographic shifts are much in focus, both because they can be fairly accurately predicted and because the consequences are potentially larger. The demographic shifts in the Scandinavian countries are roughly of the same order of magnitude. The demographic old age dependency ratio thus increases from about 0.25 to 0.4 within the next 3-4 decades, cf. figure 7. The increase is permanent due to the expected increase in longevity.

Figure 7: Demographic old age dependency ratios, 2005-2050

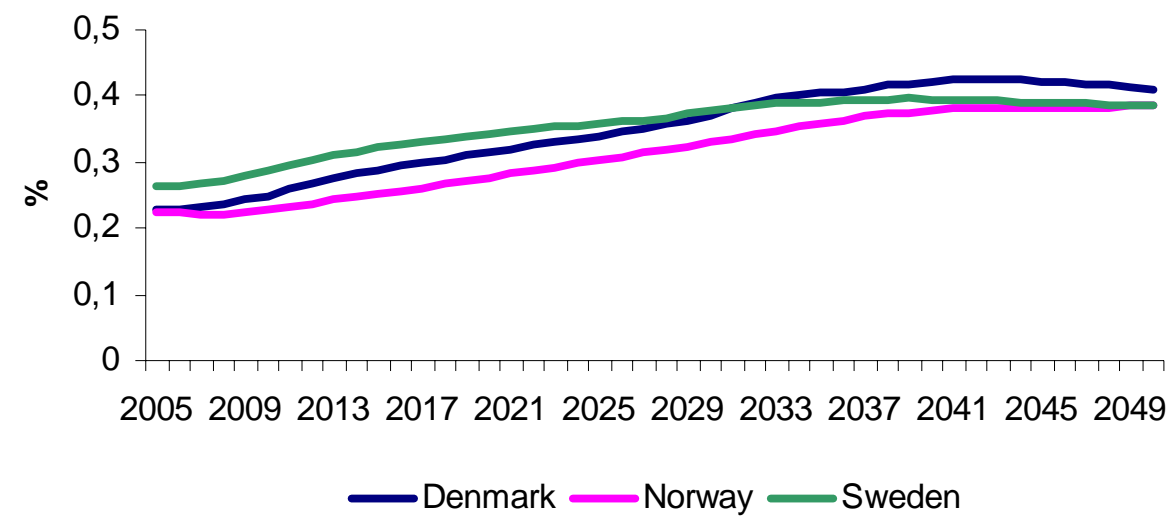

Note: Defined as the age group 65+ relative to age group 15-64.

Source: Statistics Denmark, Statistics Norway and Statistics Sweden.

Combining these demographic shifts with the properties of the social contract, cf. figure 5, immediately reveals that a financial problem will arise. Current welfare arrangements are not financially sustainable when the dependency ratio increases. The order of magnitude of the financial problems is substantial, and deteriorating public finances will lead to systematic deficits. In a recent assessment for Denmark, Velfærdskommissionen $(2004,5 b)$ finds that the problem amounts to a trend deterioration of public finances (primary balance) of about 4 percentage points of GDP between now and 2040. For Norway, the demographic consequences for public finances are among the most dramatic for OECD countries. According to estimates, the trend deterioration in the primary balance between now and 2040 is above 6 percentage 
points of GDP (Pensjonskommisjonen, 2004; Frederiksen et al., 2004). The sustainable use of petroleum wealth can finance less than $50 \%$ of the expenditure rise due to ageing. For Sweden, estimates by the OECD (2005) show that the increasing dependency ratio will continuously deteriorate public finances, and the deterioration of the budget balance between now and 2050 amounts to 4 1/2 percentage points of GDP (OECD, 2005).

The changes in the dependency ratio have two components, namely, the effect of the baby-boom generation from the 40s' approaching retirement (and the subsequent drop in fertility), and the effects of increasing longevity ${ }^{11}$. Similar demographic changes are projected for most OECD countries (see e.g. IMF (2004)). The problems arising due to the baby-boom generation are irreversible and require some adjustment. The consequences of increasing longevity are gradually developing, and there is therefore time to cope with these.

A key policy question is how to ensure that retirement ages increase alongside increases in longevity. It should be noted, however, that this cannot solve the entire problem, since letting retirement ages follow longevity is not sufficient to deal with the entire consequences of the changing dependency ratio due to the consequences of the baby-boom generation. Later retirement raises difficult policy questions, especially since average retirement ages in recent years have been declining despite increasing longevity. One can think of several reasons for this, including the rules and conditions for retirement, the labour market situation for elderly workers and preferences.

Scandinavian countries have - as other countries - various schemes which affect the retirement decision in the form of early retirement, disability pensions and the general properties of the pension system. Rather than considering the various schemes in detail, it is possible to summarize the situation by the fact that all Scandinavian countries have observed declining employment ratios for elderly. In Denmark, this is in particular due to an early retirement scheme; in Norway, it is due to early retirement as well as increasing sickness and disability pensions, and in Sweden, it is due to an increase in the number of sick people and disability pensioners.

In all Scandinavian countries, there is a debate on how to increase the retirement age. A pivotal element in the Danish debate has been the early retirement scheme. It subsidizes early retirement and is very popular, and therefore, it has proven difficult to change. Recently, the "Welfare Commission" proposed a number of measures to increase labour force participation and employment, including a phasing out of the early retirement scheme and linking the statutory pension age to longevity (Velfærdskommissionen, 2005b). In Norway, a commission evaluating the pension scheme has made a number of proposals for reforms of the 
pension scheme in order both to ensure more pension savings and later retirement. One element is to make the annual public pension benefit depend on longevity, and at the same time allow for more flexibility in retirement. The implication is that given pension benefits can be maintained by postponing retirement when longevity increases. It is currently uncertain which reforms will be undertaken. In Sweden, there was a major pension reform in the 1990s leading to substantial changes in the pension system and introducing some mechanisms by which to handle the ageing problem. The basic mechanism is that pensions are reduced if the number of old increases, i.e. in this way pension benefits are linked to longevity (see e.g. Börsch-Supan (2005)). In combination with flexible retirement possibilities this creates incentives for later retirement alongside an increase in longevity. This reform is not sufficient to avoid a pressure on public finances, cf. above, and the need for reforms is currently debated, in particular the issue of how to increase labour supply.

In debates on retirement, one often encounters the argument that the labour market discriminates elderly workers and therefore it is necessary to have fairly generous retirement options. It is a fact that the unemployment rate is higher for age groups close to the normal retirement age. However, it is potentially misleading to conclude from this that it is impossible to maintain a labour market for elderly workers. Crosscountry evidence documents a clear positive relationship between labour force participation of elderly workers and employment rates (Duval (2003)). Moreover, the age groups at which the additional unemployment is observed are very different across countries and very closely related to the rules applying in various countries. This suggests that the rules for retirement/pension play a key role. This is underlined by the fact that when comparing the Scandinavian countries (see Andersen and Pedersen (20006)), it is striking that the problems for elderly workers measured by additional unemployment are observed at age groups in the late 50s (early retirement is possible at the age of 60) in Denmark, while they are observed for the age group 62-65 in Norway and Sweden where retirement is normal at an age around 67 or 65 . This suggests that the time horizon plays an important role for both the demand and the supply side of the labour market. Hence, if rules for retirement are relaxed based on the observation that elderly workers have higher unemployment, the problem may be pushed back one step, leaving a lower retirement age and employment ratio.

Judged from policy debates there seems to be a strong preference for taking out the welfare gain caused by increasing longevity as an increase in the retirement period. Whether this is due to tax distortions or a preference shift is an open question. The former is reflected both in the implicit tax on later retirement and also in the common pool problem that single individuals do not take into account the aggregate consequences of increasing longevity and declining (relative) retirement ages. The latter is reflected in increasing reference to "the third life phase" and a change in the perception of being old from "not able to work" to "no longer working and wanting to spend time on various other activities”. 
When discussing ageing and retirement etc., it is important to point out that the balance of the social contract (cf. figure 5) depends on the number of years each individual contributes to the scheme relative to the number of years each individual benefits from the scheme. Hence, to maintain a balance when longevity increases is a question of keeping the fraction of lifetime spent in the labour market unchanged, and this can be achieved either by later retirement or earlier entry to the labour market. Naturally, the latter is conditional on whether the relevant qualifications have been acquired. However, in recent years there has been a tendency towards later labour market entry by young people, in particular in Denmark and Sweden. There is thus a need to reverse this trend, and this is an important ingredient in ensuring a balance in the social contract when longevity increases.

The ageing problem is a relative problem in the sense that the number of old people is increasing relative to the working age population, cf. figure 2. It is therefore intuitive to perceive migration as the solution. By allowing for migration to increase the working age population, the "demographic" balance can be regained, i.e. the increase in the dependency ratio can be prevented. It is often suggested that migration is the most obvious solution to the ageing problem, see e.g. IMF (2004).

There are two important reasons why it is important to distinguish between demographics and the financial problem of the welfare state. It is much easier to correct the former than the latter. The demographic changes have both a temporary and a permanent component. Migration can potentially deal with the temporary but not the permanent component. The temporary component is driven by the large cohort born after WWII and the subsequent drop in fertility rates. In the process where large cohorts retire and small cohorts enter the labour market, the dependency ratio increases, and in a welfare state with an extended social contract this obviously has important consequences. However, other things being equal the dependency ratio will fall again. Still, the problem is not trivial since demographic transitions run over decades. Whether immigration can help solve this problem depends critically on labour market consequences addressed below in section 6 .

However, there is a permanent change in the dependency ratio driven by increased longevity. For given eligibility ages this implies that the balance in the social contract is changed since the number of years as netbeneficiary increases relative to the number of years as net-contributor, cf. figure 5 . The permanent component cannot be solved by immigration since immigrants also must be expected to live longer.

Increased longevity is by most considered a welfare improvement, but the social contract would have to be revised to adapt to the change. Hence, permanent changes in welfare arrangements are needed. Basically, 
three options are available - increase taxes, lower benefits (or services) or delay retirement. The social contract needs to be adjusted to take account of increasing longevity.

\section{Baumol meets Wagner - The growth dilemma}

In policy debates, there is a strong perception that more growth will ease the financial problems of the welfare state. Hence, it seems as if the viability of the welfare state can be ensured by resorting to more popular initiatives like further investments in education and research, rather than by changing retirement and pensions systems and the like. Unfortunately, the policy choices are not that simple.

To set the scene, note that under two very basic assumptions it follows to a first approximation that public finances are not in the medium run improved by increasing growth, that is, revenues and expenditures are increasing proportionately. Increasing productivity and growth cause incomes to increase, and therefore public revenue will increase for given tax rates ${ }^{12}$. The public sector basically has two types of expenditures wages to employees and transfers. If the same number of public employees is needed (the service constraint), this cost component will increase proportionally with income since public sector wages in the medium term will have to move proportionally to private wages. To the extent the gains in living standard are to be distributed equally between the work force and recipients of income transfers to ensure an unchanged distribution between employed and non-employed (the distribution constraint), the latter component will also increase proportionally with income. Hence, revenues and expenditures move proportionally under the service and distribution constraint. Overruling the distribution constraint will by most be tantamount to a violation of basic objectives of the welfare state and hence not a viable policy option. As to the service constraint, the issue is slightly more complicated.

In the reasoning above, it was implicitly assumed that productivity increases are absent in the public sector, and therefore an unchanged amount of labour is needed if the same service provisions shall be available in the future. To put it differently, welfare services become relatively more expensive (Baumol's law). Although for some types of welfare services it may be difficult to increase productivity by the very nature of the activity (e.g. care), there surely is scope for improving productivity for a number of activities (although on average not at the same level as for e.g. industrial production). To the extent that there are such improvements, they lessen the financial constraint.

However, this should be seen in the perspective that increasing material well-being tends to increase demand for services (income elasticity above one - Wagner's law), and therefore the needs and requirements for public services increase. Which of these effects dominate is basically an empirical question driven by both technical and organisational/political mechanisms. The former relates to the scope for actually improving 
efficiency and productivity in the provision of welfare services, and the latter whether the increasing demands should be accommodated. Since, as noted in the introduction, provision of welfare services at a level which meets the needs and requirements of the larger part of the population is an essential objective of the Scandinavian welfare model, it follows that a divergent path between demand and supply of welfare services would be problematic.

The political constraint is revealed by the fact that public expenditure growth has been above the growth rate of income, and this can be interpreted as showing that in net-terms Wagner's law has been dominating. If this holds in the future, the consequences are dire. To see the order of magnitudes involved, it has been estimated for Denmark that an increase in public expenditures of just 0.15 annually above the GDP growth rate (roughly half the extra growth observed over the last 30 years) would have effects on public finances of the same order of magnitude as the demographic shifts, i.e. a deterioration of public finances of about $4 \%$ of GDP (Velfærdskommissionen (2005)).

In a forward looking perspective, there are reasons to believe that the demand pressure will dominate the possible efficiency and productivity gains to be reaped. An important case in point is health care. New technologies in medicine imply both that some treatments can be done more easily and effectively, but it also implies improved and new treatments. Ample empirical evidence documents that the latter dominates. In forecasts of health care expenses, OECD (2005) outlines various scenarios implying a substantial expenditure pressure in health care.

There is, however, a further aspect since increasing material well-being may be expected to lead to increased demand for leisure (shorter working hours, longer vacations, earlier retirement etc.). It is to be expected that the gains created by growth are to be shared between increased consumption of various forms and leisure. However, this reinforces the financial strain on the welfare state for the simple reason that leisure is not taxed. Hence, more growth may increase the demand for welfare services at the same time as it shrinks the base on which these activities are financed. The order of magnitude here is of the same size as for expenditure growth. For Denmark, a working time reduction of $0.1 \%$ per year (significantly below historical average) would have effects on public finances of the same order of magnitude as the demographic shifts, i.e. a deterioration of public finances of almost $4 \%$ of GDP (Velfærdskommissionen (2005)). The precise order of magnitudes of future increases in the demand for both improved and better welfare services as well as leisure are of course subject to uncertainty. However, the calculations reported here suggest that under relatively moderate assumptions, the effects of this "growth dilemma" can easily be as large as the effects of the demographic shifts. 
A key question here is whether the willingness to pay taxes increases along these developments. If so, there would be less of a policy dilemma created by further growth. It is not obvious that the political tensions concerning tax rates today are less than they were say 25 years ago (having reached a tax burden of about 50 $\%$ of GDP) despite the growth in incomes in the meantime. Moreover, tax distortions are increasing in the tax rate - approximately proportional to the square of the tax rate - and globalisation puts pressure on the taxation system, cf. below.

The possible tension between demand and the scope for financing welfare services raises some difficult policy dilemmas. This may cause a growing tension between what is offered and what is expected/required, which in turn may cause an increasing dissatisfaction (potentially eroding the political support for the model) with public services breaking the premise that public services are supplied at a high level that meets the needs of most. It may also lead to an increasing use of private supplements primarily sought by those who can afford it, which in turn raises distributional questions. Free and equal access is being contested. Some scope for addressing these issues can be found in user payments (which exist in all Scandinavian countries for some health services), which can be used to affect use/demand and also as a source of revenue. However, this is not eliminating the problems, and extensive use of user payments runs counter to the distributional concerns motivating “free and equal access”.

To sum, growth puts the tax financed welfare state in a financial dilemma. It tends to push expenditures in an upward direction (more and better provision of welfare services) and revenues in a downward direction (more leisure). Growth is not a new phenomenon, and it may therefore be questioned why this problem first surfaces now. The reason is that the welfare state has been in a build-up phase, and the financial base has been expanded via increases in taxes and labour force participation. Now it is in a consolidation phase where the consequences of Baumol's law (a relative price increase of welfare services) and Wagner's law (a high demand elasticity) become clear at the same.

\section{Globalization - a threat to the social contract?}

Openness and tight international integration is not a new phenomenon for the Scandinavian countries. This is, among other things, reflected in the fact that these countries are routinely classified as small and open. It is also clear that the concern for and constraints set by “international competitiveness" have played an important role. After all, the welfare state has been substantially extended in a period where the Scandinavian countries have been very well integrated in the international economy. However, this does not imply that further globalization does not raise challenges in particular due to some of the qualitative changes induced. 
At a general level, one can distinguish between three channels through which globalization may affect the welfare state, namely, taxation, spending (education and research) and migration. The challenges raised by the two first are not a threat to the basic principle of the Scandinavian welfare model, whereas migration potentially is. The three topics will be considered in turn.

\subsection{Taxation}

Since the Scandinavian welfare model is tax financed and therefore implies high tax rates, much focus has been on the question whether high tax rates are sustainable in a more globalized world. Much of this debate has been concerned with increasing tax base mobility. The basic mechanism is that the more mobile a given tax base, the more difficult it is to tax at a rate (significantly) above that of your close trading partners. To avoid loss of tax revenue due to further integration, the response must be lower tax rates, which in turn may erode tax revenue. A more aggressive response would be to undercut the tax rates of trading partners (i.e. tax competition leading to a race-to-the-bottom mechanism) in the hope of attracting more economic activity. Another response would be to change the tax structure, lowering taxes on mobile tax bases and increasing them on less mobile tax bases.

The Scandinavian countries have gradually adapted their tax structure to cope with some of these changes, in particular via the so-called dual income taxation system (see e.g. Larsen and Sørensen (2003)), allowing a proportional taxation of capital income to be combined with progressive taxation of other forms of income. Therefore, it has been possible to adjust taxation of capital income and corporations to lower levels to match rates observed in competing countries while maintaining relatively high tax rates (and progressive elements) on labour income. They have also followed the trend of lowering corporate tax rates accompanied by some broadening of the tax base. Tax adjustments have also been made in specific areas such as excise taxes on e.g. alcohol to cope with problems arising from increased cross-border trade.

While the issue of tax base mobility is important and raises a number of important and difficult questions concerning the tax system and control etc., it is an issue of second-order importance in relation to the overall question of the financing of the welfare state ${ }^{13}$. This is so since the predominant part of tax revenue is raised via direct and indirect taxation in various forms of income generated in the labour market. The key question is thus how the scope for taxation of labour is affected by the globalization process.

Tax distortions may be affected by globalization. With more easy options of relocating production and thus employment, it follows that job mobility increases. That is, employment creation becomes more sensitive to domestic conditions. If a larger fraction of jobs due to international integration are created in sectors with a more elastic labour demand, it follows unambiguously that the distortionary consequences of taxes levied on 
labour are non-decreasing (see Andersen (2003)). Accordingly, the tax distortions increase alongside international integration, or to put it differently, the costs of raising tax revenue via taxation of labour increase. Moreover, and possibly even more importantly, a tendency - as observed - to towards more decentralized wage setting would reinforce these problems ${ }^{14}$. As noted above under centralized wage setting, tax distortions may be lower because the public budget constraint is internalized. In a process where labour markets become more decentralized either due to international integration or due to other forces, it follows that tax distortions are on the increase.

\subsection{Spending}

Globalization may create a spending pressure. This is primarily driven by the effects of globalization on labour markets. Alongside technological change, globalization tends to induce a skill-bias in the demand for labour, i.e. decreasing demand for unskilled and increasing demand for skilled. Given the structure of labour markets, this tends to increase unemployment and thus the burden on social transfers, i.e. other things being equal there is a risk that it lowers the employment ratio.

To avoid this it is commonly agreed that the educational level of the work force should be increased, in particular for the groups having no education beyond mandatory schooling. The idea is to counter the skillbias in demand via a reverse skill-bias in supply. While empirical evidence supports that this has worked in the past (see e.g. Fosgerau et. $\mathrm{Al}$ (2000)), it also points to an expenditure pressure to avoid a declining employment ratio. Hence, the financial constraint is tightened by these effects of globalization.

\subsection{Migration}

Increased migration is in particular a potentially important problem for the universal or Scandinavian model. The reason lies in the fact that the welfare model is comparable to an encompassing implicit (social) insurance contract, and like any insurance market, it becomes problematic if adverse or self selection implies that the "good" risks leave and the "bad" risks enter. The key determinant here is the labour market position of the potential emigrants and immigrants since this determines whether the person in financial terms is a net contributor or a net beneficiary to the welfare state. A problem arises if immigrants tend to have a below average attachment to the labour market since they would then be net beneficiaries of the welfare system. A parallel problem arises if there is an overrepresentation of highly educated individuals among emigrants since they tend to be higher net contributors to public finances. For these reasons, migration is a challenge which may have potential wide ranging implications for the Scandinavian welfare model.

This creates some crucial dilemmas in economic policy. Consider first education and emigration. The public sector offers free education to provide equal opportunities and to reduce the risk in educational decisions. 
Expenditures on education are financed via general taxation with some progressive elements, implying that those turning out to have the highest incomes after education will also pay the most in taxes. However, this model is vulnerable to mobility since the migration decision can be taken after benefiting from publicly financed education and the veil of ignorance in relation to labour market prospects has been lifted. Moreover, by moving to countries relying more on private financing of education and therefore having lower taxes and more wage dispersion, the individual gains from mobility can be high.

The potential importance of increased emigration of the highly educated for public finances is very large. However, for the time being one cannot argue that this is a major problem, see e.g. Pedersen et al. (2003). Although there is some emigration of the highly educated, return migration is also high. However, future migration flows of the highly educated can be expected to move in only one direction. Various barriers to mobility such as language, culture and travelling time are reduced, and competition between countries to attract highly educated labour has intensified. ${ }^{15}$

Immigration is a very topical issue. The immigration pressure from low income countries is large. Over the past decades, all Nordic countries have experienced increased immigration from low income countries, and they face a number of challenges ${ }^{16}$. The primary challenge is integration of immigrants into the labour market. The problems here arise from the combination of two key features of the Scandinavian welfare model, namely, the distributional constraint implying high minimum wages and the requirement of a high employment rate. In short, the model has high demands for the qualifications of the work force (qualifications must be worth at least the minimum wages) and, at the same time, many are expected/needed to meet these requirements. ${ }^{17}$.

All Nordic countries face problems of ensuring that the employment ratio of immigrants reaches the same level as the rest of the population. Some of these problems are related to the structure of welfare arrangements for the reasons explained above. Figure 8 shows for a number of countries the difference between the employment frequency of the population and that of immigrants from low income countries. Scandinavian countries stand out with a large discrepancy between resident and migrant labour force participation, in particular for women. 
Figure 8: Employment gaps - immigrants and descendants from low income countries relative to native

Females

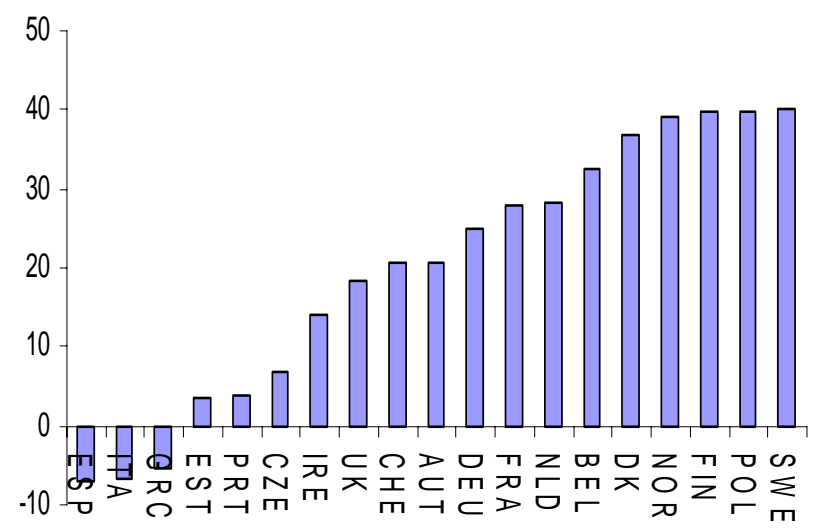

Males

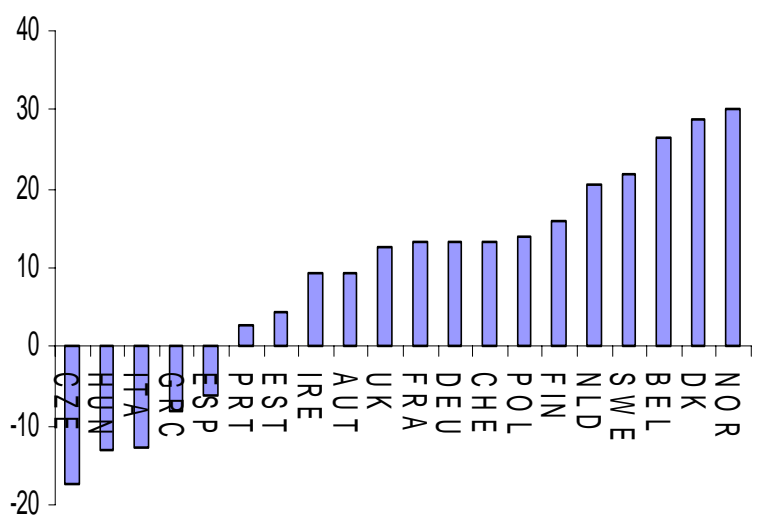

Source: Velfærdskommissionen (2005)

A number of factors can explain the difference. The gender gap reflects that female labour force participation has become the norm in the Scandinavian countries. It is an integral part of the welfare model and reflects a different position of women in society compared to many low income countries. In addition, most immigrants from low income countries have low qualifications, and this poses a particular problem in the Scandinavian countries since a compressed wage structure with high minimum wages implies that it is difficult for the low skilled to find work. ${ }^{18}$

For Denmark, assessments have been made of the implications of immigration from low income countries for the social contract, presuming that the current low labour force participation rate is maintained. Unsurprisingly, it is found that this form of immigration worsens the fiscal sustainability problem. In a counterfactual path with no further immigration from low income countries, it is shown that the problem of fiscal sustainability due to demographic shifts is reduced by about 3/4 (Velfærdskommissionen (2005)).

These problems have raised a delicate political problem in relation to immigration policy, namely, whether it is the immigration rules or the principles of the welfare state that should give in. Both have happened in Denmark. Immigration laws have been tightened, and the universal principle has been modified. To qualify for eligibility in the social safety net, there is now an entry condition since one must have been a resident in Denmark for 7 of the past 8 years. If this condition is not met, one is only entitled to a social benefit (starthjælp/introduktionsydelse) at roughly half the level in the ordinary social system (kontanthjælp). Both of these measures are controversial and have been much debated. 
In all the Scandinavian countries, there is an ongoing debate on how to strengthen the labour market integration of immigrants as well as how to reconcile basic principles of the welfare model with "open borders". In a similar vein, there is much discussion about the risk of "brain drain" by emigration of the highly educated as well as the scope for attracting highly educated emigrants via tax rebates or more flexible immigration rules.

\section{Direction for policy reforms and welfare regimes}

The Scandinavian countries have an extended welfare state, and have managed to combine a high income level with a fairly equal income distribution. Although there are many exceptions to the rule, welfare arrangements have a universal character with individual entitlements for all and collective financing via taxation. Pivotal for the financial viability of this model is that a high fraction of the population is in employment. The possibility of ensuring this is challenged by demographic changes, the growth dilemma and the effects of globalization. These problems may be intensified to the extent that work norms are changing, implying further pressure on welfare arrangements and difficulties in maintaining a high employment ratio.

The policy dilemma is that many of the instruments with potential for increasing the employment rate run counter to other objectives. This applies in particular in relation to the distributional concerns, but also the preferences of the population. Policy debates often leave a gap between proposals to increase work and employment and the widespread perception that the work effort is already high as well as the demand for more leisure. This contrast is perhaps most visible in debates on the need to induce later retirement in tandem with the increasing longevity. This is often portrayed as a retrenchment of the welfare state when it is in fact a necessary adjustment of the social contract to changes in welfare improvement made possible by an increase in longevity.

Is the Scandinavian model more vulnerable to globalization? On the one hand, the model has been developed in very internationally integrated economics, and it has historically been possible to combine extended welfare arrangement with "international competitiveness". On the other hand, globalization is taking a new form strengthening pressure on tax bases via mobility and migration. Considering the scope for policy decisions, we are still far from a situation where the power of domestic politicians has been eroded, and there is ample of scope to influence policies. Internal and external challenges create a need for adjustment and reform, but not for a radical change in welfare regime. Empirical evidence has also documented a substantial persistence in welfare regimes across countries, and it is therefore not to be expected that reform processes in the Scandinavian countries will lead to fundamental changes in the basic principles underlying welfare arrangements. However, reforms and adjustment are needed to make the Scandinavian welfare model viable. 


\title{
Notes
}

\begin{abstract}
${ }^{*}$ Comments and suggestions by the discussants Lars Jonung and Paul Scnabel as well as participants at the conference ”Reinventing the Welfare State”, The Hague, April 2006, are gratefully acknowledged.
\end{abstract}

${ }^{1}$ Whether the term "the Scandinavian welfare model” is well-defined can be questioned. It is used here in the broad sense of universal and generous welfare arrangements, with the explicit proviso that such welfare arrangements are not confined to a particular geographical area.

${ }^{2}$ The difference in the extent to which various services are undertaken in the public sector or privately can cause a bias in international comparisons of income levels.

${ }^{3}$ E.g. to be entitled to social assistance in Denmark, it is a requirement that some social event is present (illness, divorce, loss of spouse, unemployment). The changes must be so substantial that self-support is not possible, and moreover, it should be caused be exogenous forces which could not be foreseen. The benefit is means tested (family income).

${ }^{4}$ It is not without problems to compare resource allocation via the public sector across countries (see e.g. Adema (2001)). One reason is that there can be huge differences solely from the fact that some countries have transfers to be taxable income, while in others, transfers are not taxable income.

${ }^{5}$ The estimate is for Denmark and based on the effects of a drop in private employment among people who are entitled to unemployment benefits. Calculated on the basis of analyses in Velfærdskommissionen (2005).

${ }^{6}$ In policy debates, this is often made a question of laziness. Do people want to work or not? This is a too narrow perspective to take on the participation decision. The real issue is how the whole complex of social and labour market policies affects the reservations demands (wage, type of job, willingness to commute etc.) for accepting a job. The higher the reservation demands in any of these dimensions, the less is the active labour market participation.

${ }^{7}$ If there is some disutility to participate actively in the labour market, the participation constraint can be met either by lowering benefits or by the demands in activation schemes. Hence, to any benefit level there is a corresponding activation requirement leaving the same incentive to work.

${ }^{8}$ The minimum wage is decided by law in Norway and Sweden, while in Denmark, it is negotiated between the labour market parties. 
${ }^{9}$ The way education is organised and financed may also affect the type of education being demanded. Moreover, there is an issue on how much education is used (hours supplied, retirement etc.)

${ }^{10}$ For theoretical analyses developing these ideas, see e.g. Eaton and Rose (1980), Varian (1980), Sinn (1995) and Acemogly and Shimer (2000).

${ }^{11}$ Velfærdskommissionen $(2004,2005 a)$ documents that the permanent component in the demographic shift accounts for the major part of the fiscal sustainability problem for current welfare arrangements.

${ }^{12}$ In practice, this is not quite correct. Since some tax bases are depending on past income (e.g. taxation of pension funds), there will be a revenue drag if growth goes up, because not all tax bases grow at the same rate. See Andersen and Pedersen (2006) for a further discussion.

${ }^{13}$ This is supported by a quantitative assessment made by Sørensen (2000) of the implications of tax base mobility and tax competition for capital income taxation and corporate taxation. In accordance with theory, he finds that such taxes become inefficiently low, but compared to the initial situation, the consequences are very small in terms of production, employment etc. The important question is thus concerned with the direct and indirect implications for international integration for taxation of labour income.

${ }^{14}$ It is well documented that labour markets in the Scandinavian countries are becoming more decentralized (see Boeri et al. (2001)).

${ }^{15}$ It is often argued that high marginal tax rates on labour income are a particular problem in relation to migration for the highly educated. However, a migration decision is not a marginal decision, and is therefore affected by the whole welfare package, i.e. tax payments, but also the various entitlements.

${ }^{16}$ Immigration rules for refugees follow UN conventions. Since 2002, Denmark has had stricter rules for family unification. Immigration for economic reasons is only allowed if there are special labour market needs, except for European citizens where the rules are in accordance with the EU/EØS agreement on labour mobility.

\footnotetext{
${ }^{17}$ Note that this argument also holds even if immigration as such is not driven by the generosity of welfare arrangements (welfare magnets). Recent empirical work did not find evidence of selection effects driven by welfare arrangements, but this can be due to restrictive immigration rules, cf. Pedersen et al. (2004).
} 
${ }^{18}$ In addition, the economic gains from being active in the labour market can, for some groups, be small or absent, and finally there are incidences of discrimination. Comparing integration of immigrants in Denmark and Germany in Rockwool (2004), it is found that both countries had difficulties. The relative better performance of Germany can be attributed to i) better qualifications among immigrants, ii) lower minimum wages and iii) a large economic incentive to be in employment. 


\section{References}

Accemoglu, D and R. Shimer (2000) Efficient Unemployment Insurance, Journal of Political Economy

Adema, W. (2001) Net Social Expenditures, Working Paper, OECD

Agell, J. (2002) On the determinants of labour market institutions: rent seeking vis social insurance, German Economic Review, 3, 107-135.

Andersen, T.M. (2003) Welfare policies, labour taxation and international integration, International Tax and Public Finance, 10, 43-62.

Andersen, T.M. (2004) Challenges to the Scandinavian welfare model. In: European Journal of Political Economy, 20, pp. 743-754.

Andersen, T.M., and L.H. Pedersen (2006) Assessing fiscal sustainability and the consequences of reforms, to appear European Commission.

Andersen, T.M., and M. Svarer (2006) Flexicurity - the danish labour market model, Ekonomisk Debatt. Boeri, T., A. Brugiavini and L. Clamfors (eds.)., 2001, The Role of Trade Union in the Twenty-First Century, Oxford University Press.

Börsch-Supan, A. (2005) From traditional DB to notional DC systems: The pension reform process in Sweden, Italy and Germany. In: Journal of the European Economic Association, Papers and Proceedings, 3, pp. 458-465.

Calmfors, L., A. Forslund, and M. Hemström (2002) Does active labour market policy work? Lessons from the Swedish experience?, Seminar paper 700, Institute for International Economic Studies, Stockholm University.

Duval, R. (2004) Retirement behaviour in OECD countries: Impact of old-age pensions schemes and other social transfer programmes, OECD Economic Studies,37.

Eaton, J. and H.S. Rosen (1980) Taxation, human capital and uncertainty, American Economic Review, $70,705-15$

Finansdepartementet (2004) Långtidsutredningen 2003/4, Statens Offentliga Utredninger 2004:19, Stockholm. 
Fosgerau, M., S.E. Hougaard Jensen, and A. Sørensen (2000) Relative demand shifts for educated labour, CEBR Discussion paper, 200-11.

Frederiksen, D., K.M. Heide. E. Holmøy and I.F. Solli (2005) Makroøkonomiske virkninger av pensjonsreformer - Beregninger baseret på forslag fra Pensjonskommissionen, Working Paper, Statistics Norway.

de la Fuente, A. (2003) Human Capital in a Global and Knowledge Based Economy, European Commission, Economic Papers, Directorate-General for Employment and Social Affairs.

Graafland, J.J. (2000) Childcare subsidies, labour supply and public finance: an AGE approach, Economic Modelling, 17, 209-246

Hansen, H. (2004) Social Security Systems, Institute for Social Research, Copenhagen.

Larsen, D., and P.B. Sørensen (2003) Financing the Nordic Welfare States, In "Det fremtida nordiske välfärdssamhället - Utmaningar och möjligheter, Nordiska Ministerrådet.

Lindbeck, A., S. Nyberg and J.W. Weibüll (2003) Social Norms and Welfare State Dynamics, Journal of the European Economic Association, 1, 533-542.

OECD (2005) Economic surveys, Paris.

OECD (2006) Projecting OECD health and long-term care expenditures: What are the main drivers, Economics Deparments, Workings Papers 477.

IMF (2004) World Economic Outlook - The Global Demographic Transition. September 2004, Washington. Marshal, T.H. (1950) Citizenship and Social Class.

Nordic Social-Statistical Committee (2005)

Pedersen. P.J., Røed, M., \& Schröder, L. (2003) Emigration from the Scandinavian welfare states. In: T.M. Andersen and P. Molander (Ed) Alternatives for Welfare Policy - Coping with Internationalisation and Demographic Change. Cambridge University Press.

Pedersen, P.J., Pytlikova, M. \& Smith, N. (2004) Selection or Network Effects? Migration flows into 27 OECD countries, 1990-2000. IZA Discussion Paper 1104. 
Pensjonskommisjonen (2004) Moderniseret Folketrygd - Bærekraftig Pensjon for Fremtida. NOU, Norges Offentlige Udredninger 2004:1.

Rockwool Fondens Forskningsenhed (2004) Migrants, Work, and the Welfare State, ed. by T. Tranæs and K.

F. Zimmermann. Copenhagen: The Rockwool Foundation Research Unit.

Sinn, H.W. (1995) A Theory of the Welfare State, Scandinavian Journal of Economics, 97,495-526.

Summers, L, Gruber J. and R. Vegara (1993) Taxation and the structure of labour markets, Quarterly Journal of Economics, 94,385-411.

Sørensen, P.B. (2000) The case for international tax co-ordination reconsidered, Economic Policy,430-472.

Van der Noord, P. (2001) Automatic Stabilizers, OECD working paper

Varian, H. (1980) Redistributive taxation as social insurance, Journal of Public Economics,14, 49-68

Velfærdskommissionen (2005a) Fremtidens Velfærd - Globalisering, Analyserapport. Copenhagen.

Velfærdskommissionen (2005b) Fremtidens Velfærd - Sådan gør andre lande, Analyserapport.

Copenhagen. 


\section{CESifo Working Paper Series}

(for full list see www.cesifo-group.de)

1844 Eytan Sheshinski, Differentiated Annuities in a Pooling Equilibrium, November 2006

1845 Marc Suhrcke and Dieter Urban, Are Cardiovascular Diseases Bad for Economic Growth?, November 2006

1846 Sam Bucovetsky and Andreas Haufler, Preferential Tax Regimes with Asymmetric Countries, November 2006

1847 Luca Anderlini, Leonardo Felli and Andrew Postlewaite, Should Courts always Enforce what Contracting Parties Write?, November 2006

1848 Katharina Sailer, Searching the eBay Marketplace, November 2006

1849 Paul De Grauwe and Pablo Rovira Kaltwasser, A Behavioral Finance Model of the Exchange Rate with Many Forecasting Rules, November 2006

1850 Doina Maria Radulescu and Michael Stimmelmayr, ACE vs. CBIT: Which is Better for Investment and Welfare?, November 2006

1851 Guglielmo Maria Caporale and Mario Cerrato, Black Market and Official Exchange Rates: Long-Run Equilibrium and Short-Run Dynamics, November 2006

1852 Luca Anderlini, Leonardo Felli and Andrew Postlewaite, Active Courts and Menu Contracts, November 2006

1853 Andreas Haufler, Alexander Klemm and Guttorm Schjelderup, Economic Integration and Redistributive Taxation: A Simple Model with Ambiguous Results, November 2006

1854 S. Brock Blomberg, Thomas DeLeire and Gregory D. Hess, The (After) Life-Cycle Theory of Religious Contributions, November 2006

1855 Albert Solé-Ollé and Pilar Sorribas-Navarro, The Effects of Partisan Alignment on the Allocation of Intergovernmental Transfers. Differences-in-Differences Estimates for Spain, November 2006

1856 Biswa N. Bhattacharyay, Understanding the Latest Wave and Future Shape of Regional Trade and Cooperation Agreements in Asia, November 2006

1857 Matz Dahlberg, Eva Mörk, Jørn Rattsø and Hanna Ågren, Using a Discontinuous Grant to Identify the Effect of Grants on Local Taxes and Spending, November 2006

1858 Ernesto Crivelli and Klaas Staal, Size and Soft Budget Constraints, November 2006 
1859 Jens Brøchner, Jesper Jensen, Patrik Svensson and Peter Birch Sørensen, The Dilemmas of Tax Coordination in the Enlarged European Union, November 2006

1860 Marcel Gérard, Reforming the Taxation of Multijurisdictional Enterprises in Europe, "Coopetition" in a Bottom-up Federation, November 2006

1861 Frank Blasch and Alfons J. Weichenrieder, When Taxation Changes the Course of the Year - Fiscal Year Adjustments and the German Tax Reform 2000/2001, November 2006

1862 Hans Jarle Kind, Tore Nilssen and Lars Sørgard, Competition for Viewers and Advertisers in a TV Oligopoly, November 2006

1863 Bart Cockx, Stéphane Robin and Christian Goebel, Income Support Policies for PartTime Workers: A Stepping-Stone to Regular Jobs? An Application to Young LongTerm Unemployed Women in Belgium, December 2006

1864 Sascha O. Becker and Marc-Andreas Muendler, The Effect of FDI on Job Separation, December 2006

1865 Christos Kotsogiannis and Robert Schwager, Fiscal Equalization and Yardstick Competition, December 2006

1866 Mikael Carlsson, Stefan Eriksson and Nils Gottfries, Testing Theories of Job Creation: Does Supply Create Its Own Demand?, December 2006

1867 Jacques H. Drèze, Charles Figuières and Jean Hindriks, Voluntary Matching Grants Can Forestall Social Dumping, December 2006

1868 Thomas Eichner and Marco Runkel, Corporate Income Taxation of Multinationals and Unemployment, December 2006

1869 Balázs Égert, Central Bank Interventions, Communication and Interest Rate Policy in Emerging European Economies, December 2006

1870 John Geweke, Joel Horowitz and M. Hashem Pesaran, Econometrics: A Bird's Eye View, December 2006

1871 Hans Jarle Kind, Marko Koethenbuerger and Guttorm Schjelderup, Taxation in TwoSided Markets, December 2006

1872 Hans Gersbach and Bernhard Pachl, Cake Division by Majority Decision, December 2006

1873 Gunther Schnabl, The Evolution of the East Asian Currency Baskets - Still Undisclosed and Changing, December 2006

1874 Horst Raff and Michael J. Ryan, Firm-Specific Characteristics and the Timing of Foreign Direct Investment Projects, December 2006 
1875 Jukka Pirttilä and Håkan Selin, How Successful is the Dual Income Tax? Evidence from the Finnish Tax Reform of 1993, December 2006

1876 Agnieszka Stążka, Sources of Real Exchange Rate Fluctuations in Central and Eastern Europe - Temporary or Permanent?, December 2006

1877 Xavier Calsamiglia, Teresa Garcia-Milà and Therese J. McGuire, Why do Differences in the Degree of Fiscal Decentralization Endure?, December 2006

1878 Natacha Gilson, How to be Well Shod to Absorb Shocks? Shock Synchronization and Joining the Euro Zone, December 2006

1879 Scott Alan Carson, Modern Health Standards for Peoples of the Past: Biological Conditions by Race in the American South, 1873 - 1919, December 2006

1880 Peter Huber, Michael Pfaffermayr and Yvonne Wolfmayr, Are there Border Effects in the EU Wage Function?, December 2006

1881 Harry Flam and Håkan Nordström, Euro Effects on the Intensive and Extensive Margins of Trade, December 2006

1882 Panu Poutvaara and Mikael Priks, Hooliganism in the Shadow of the 9/11 Terrorist Attack and the Tsunami: Do Police Reduce Group Violence?, December 2006

1883 Ruud A. de Mooij and Gaëtan Nicodème, Corporate Tax Policy, Entrepreneurship and Incorporation in the EU, December 2006

1884 Johannes Becker and Clemens Fuest, Corporate Tax Policy and International Mergers and Acquisitions - Is the Tax Exemption System Superior?, January 2007

1885 Momi Dahan and Udi Nisan, The Effect of Benefits Level on Take-up Rates: Evidence from a Natural Experiment, January 2007

1886 José García-Solanes, Francisco I. Sancho-Portero and Fernando Torrejón-Flores, Beyond the Salassa-Samuelson Effect in some New Member States of the European Union, January 2007

1887 Peter Egger, Wolfgang Eggert and Hannes Winner, Saving Taxes Through Foreign Plant Ownership, January 2007

1888 Timothy J. Goodspeed and Andrew Haughwout, On the Optimal Design of Disaster Insurance in a Federation, January 2007

1889 Wim Groot, Henriëtte Maassen van den Brink and Bernard van Praag, The Compensating Income Variation of Social Capital, January 2007

1890 Bas Jacobs, Ruud A. de Mooij and Kees Folmer, Analyzing a Flat Income Tax in the Netherlands, January 2007 
1891 Hans Jarle Kind, Guttorm Schjelderup and Frank Stähler, Newspapers and Advertising: The Effects of Ad-Valorem Taxation under Duopoly, January 2007

1892 Erkki Koskela and Rune Stenbacka, Equilibrium Unemployment with Outsourcing under Labour Market Imperfections, January 2007

1893 Maarten Bosker, Steven Brakman, Harry Garretsen, Herman de Jong and Marc Schramm, The Development of Cities in Italy 1300 - 1861, January 2007

1894 Michel Beine, Oscar Bernal, Jean-Yves Gnabo and Christelle Lecourt, Intervention Policy of the BoJ: A Unified Approach, January 2007

1895 Robert S. Chirinko and Daniel J. Wilson, State Investment Tax Incentives: A Zero-Sum Game?, January 2007

1896 Theo S. Eicher and Oliver Roehn, Sources of the German Productivity Demise Tracing the Effects of Industry-Level ICT Investment, January 2007

1897 Helge Berger, Volker Nitsch and Tonny Lybek, Central Bank Boards around the World: Why does Membership Size Differ?, January 2007

1898 Gabriel Felbermayr and Wilhelm Kohler, Does WTO Membership Make a Difference at the Extensive Margin of World Trade?, January 2007

1899 Benno Torgler and Friedrich Schneider, The Impact of Tax Morale and Institutional Quality on the Shadow Economy, January 2007

1900 Tomer Blumkin and Efraim Sadka, On the Desirability of Taxing Charitable Contributions, January 2007

1901 Frederick van der Ploeg and Reinhilde Veugelers, Higher Education Reform and the Renewed Lisbon Strategy: Role of Member States and the European Commission, January 2007

1902 John Lewis, Hitting and Hoping? Meeting the Exchange Rate and Inflation Criteria during a Period of Nominal Convergence, January 2007

1903 Torben M. Andersen, The Scandinavian Model - Prospects and Challenges, January 2007 